\title{
Perceived important managerial competencies for healthcare managers at a tertiary healthcare institution in Calabar, Cross River State, Nigeria
}

\author{
Uchenna Okonkwo*1, Bennardine Ekpeyoung ${ }^{2}$, Antor Ndep ${ }^{2}$ \\ ${ }^{1}$ Department of Internal Medicine, University of Calabar, Cross River State, Nigeria \\ ${ }^{2}$ Department of Public Health, University of Calabar, Cross River State, Nigeria
}

Received: October 10, 2019

DOI: $10.5430 /$ jha.v9n1p18
Accepted: December 18, 2019 Online Published: December 30, 2019

URL: https://doi.org/10.5430/jha.v9n1p18

\begin{abstract}
Background: Management in healthcare industry has evolved over the years. There is increasing need for healthcare managers to acquire new skill sets particularly those related to strategic planning and business management.

Aims: We sought to determine managerial competencies perceived as importsnt for healthcare managers in a tertiary healthcare institution in Calabar, Nigeria.

Methods: A structured questionnaire (modeled after the Health Leadership Alliance competency questionnaire) was selfadministered to 266 randomly selected managers comprising 5 strategic managers, 53 middle managers and 208 operational managers. Data were analyzed using SPSS version 20.

Results: A total of 266 managers were included in this study with a M: F ratio of 1.3: 1. The findings of this study showed that operational, middle and strategic managers rated 27,37 and 46 of the competencies as contributing significantly with a mean rating of $\geq 4$. Important/essential competencies differed between the three tiers of management. Competencies related to financial/business management were not considered very important. The result from qualitative arm synchronized with the quantitative arm to some extent, and provided insight to the managers' perspective.

Conclusions: The findings of this study highlights the incongrous paradigm between managerial level and perceived important management competencies and supports the belief that there is inadequate managerial capacity especially those related to financial/business management.
\end{abstract}

Key Words: Management competency, Tertiary healthcare managers, Nigeria

\section{INTRODUCTION}

Management in organization requires the coordination of the efforts of different individuals to accomplish set goals and objectives by using available resources efficiently and effectively. ${ }^{[1]}$ Healthcare management is a profession that has changed immensely over the last decade particularly in developed countries. In both the public and private sector, changing government regulations on healthcare practices and consumer needs have challenged the skills of traditional healthcare managers with predominantly technical expertise in a field of medical practice. ${ }^{[2]}$ As stated by Peter Druker, "the world in which the healthcare professionals learned to manage (practice) no longer exists". Clinical competencies

\footnotetext{
*Correspondence: Uchenna Okonkwo; Email: ucsuizes@yahoo.co.uk; Address: Department of Internal Medicine, University of Calabar, Cross River State, Nigeria.
} 
are no longer enough. There is increasing need for healthcare professionals to learn new sets of skills especially those related to strategic planning, logical, creative and holistic thinking, financial/business management and team work in order to achieve an effective system of healthcare delivery that is responsive to the health needs of the people. ${ }^{[3]}$

In Nigeria, tertiary healthcare institutions are strategically managed by healthcare professionals with basically clinical qualifications and seconded by persons with management qualifications unlike in most developed countries where the management of hospitals have been taken over by professional managers with the aim of improving productivity and business performance of health institutions. ${ }^{[4]}$ Of 6,500 hospitals sampled in the United States of America in 2009, only 235 are led by physician-managers. ${ }^{[5]}$

The tertiary health care institution in Nigeria is beleaguered with myriad problems which have hampered its effectiveness and efficiency in the process of health care delivery. The inability of policy makers and hospital managers to coordinate actions, prioritize and judiciously utilize scarce health resources to meet the health care needs of the citizens constitutes a major public health problem manifesting as incessant strike action by various groups of healthcare professionals, crumbling infrastructure, chronic out-of-stoke syndrome, poor processes and outcomes, escalating medical tourism amongst others. ${ }^{[6-8]}$ The concept of this study is underpinned in the competency-based theory which is a relatively new way of thinking about how organizations can gain high performance and sustain it over time. ${ }^{[9,10]}$ It incorporates economic, organizational and behavioral concerns in a framework that is dynamic, systemic, cognitive and holistic. ${ }^{[11,12]}$ The aim of this study was to determine managerial competencies perceived as important amongst healthcare managers at a tertiary healthcare institution in Calabar, Cross River State and thus contribute data to help reposition Nigerian healthcare managers for 21 st century healthcare industry.

\section{Objectives of the study}

(1) Determine perceived important management competencies required by health managers

(2) Determine association between level of management and important management competencies

\section{MeTHODS}

The study was carried out at the University of Calabar Teaching Hospital, Cross River State, one of the 56 federal tertiary healthcare institutions in Nigeria. The study had both quantitative and qualitative component. A structured questionnaire (modeled after the Health Leadership Alliance competency questionnaire), ${ }^{[13]}$ which comprised 5 domains (healthcare environment, communication/relationship, professionalism, leadership, business/financial management) and 46 competency items was self administered to 266 randomly selected managers. A Likert scale on rating level of importance of the competency statements on current managerial role ranged from 1-5 with 1 implying "not important", 2 "minimally important", 3 "moderately important", 4 "significantly important", and 5 "essential" for the management position. The instrument that was used for data collection in the qualitative arm was an interview guide designed by the researcher and modeled after the quantitative data instrument (see Appendix 1). The interview was conducted by the researcher in the respondents' office. A voice recorder was used to record the interview.

\subsection{Sample size calculation}

The sample size for this study was calculated using the formula (see Equation 1). ${ }^{[14]}$

$$
n=\frac{z^{2} p q}{d^{2}}
$$

Where $n=$ sample size, $Z=$ confidence interval of $95 \%, p=$ prevalence, $q=1-p, d=$ the desired precision which is $5 \%$.

Substituting the above values (see Equation 2),

$$
\begin{aligned}
n & =\frac{z^{2} p q}{d^{2}}=\frac{(1.96)^{2} \times 0.196 \times(1-0.196)}{(0.05)^{2}} \\
& =\frac{3.84 \times 0.196 \times 0.804}{0.0025}=\frac{0.605}{0.0025}=242
\end{aligned}
$$

Ten percent of calculated sample size was added to account for non-response $=266$.

\subsection{Sampling procedure}

\section{Selection of managers or respondents}

There are two directorates at the University of Calabar Teaching Hospital; the directorate of administration comprising 19 departments and 42 units and the directorate of clinical services comprising 41 departments and 192 units. A proportionate sampling technique was employed to determine the number of persons to be sampled from each category of managers. Simple random sampling was used to select 5 strategic managers, 53 middle managers ( 35 from the clinical department and 18 from the non-clinical department) and 208 operational managers (166 from the clinical units and 42 from the non-clinical units). 


\subsection{Selection of respondents for the key informant interview}

Nine managers consisting of 2 strategic, 3 middle and 4 operational managers were selected for the interview. This number was deemed adequate to get to saturation point. The interview guide used is shown in Appendix 1.

\subsection{Data analysis}

Statistical analysis was performed using the statistical package for social sciences (SPSS) version 20. Categorical variables were calculated as frequencies and percentages. The competency ratings assigned to each item by participants in the study were totaled and the means and standard deviations were calculated. The higher the mean score on a competency statement, the more essential it is to the role of healthcare managers. One way Anova was used to test for the significance of difference in ratings between groups of subjects in the study and post-hoc tests were done to determine difference between sub-groups. $P$-value of $<.05$ was considered significant. For the qualitative data, the recorded interviews were transcribed and manually analyzed using a deductive approach based on the pre-identified themes in the interview guide. Verification of the thematic codes was done through reading and re-reading of the quotes.

\subsection{Ethical clearance}

A letter of ethical clearance was obtained from the Ethics committee, University of Calabar Teaching Hospital, Calabar. Informed consent was obtained from the participants after assuring of the confidentiality of study.

\section{RESULTS}

This study showed that of the 46 competency statements rated by participants for their importance to managers, operational, middle and strategic managers rated 27, 37 and 46 of the competencies respectively as contributing significantly with a mean rating of $\geq 4$.

Analysis of the healthcare environment domain showed that both operational and middle managers considered clinical/technical skills most important with respective mean scores of $4.42 \pm 0.83$ and $4.4 \pm 0.77$. Strategic managers rated research and evidence based practice, role of clinical professionals and new technology as significantly important with a mean score of $4.75 \pm 0.5$ each (see Table 1 ).

Table 1. Importance rating of competency statements on healthcare environment

\begin{tabular}{lccccccc}
\hline Knowledge item & $\begin{array}{c}\text { Operational } \\
\text { manager }\end{array}$ & Rating & $\begin{array}{c}\text { Middle } \\
\text { manager }\end{array}$ & Rating & $\begin{array}{c}\text { Strategic } \\
\text { manager }\end{array}$ & $\begin{array}{c}\text { Rating } \\
\boldsymbol{p} \text {-value }\end{array}$ \\
\hline Regulatory agency standards & $4.16 \pm 0.88$ & 6 & $4.14 \pm 0.93$ & 4 & $4.4 \pm 0.54$ & 3 & .81 \\
Clinical/technical skills & $4.42 \pm 0.83$ & 1 & $4.4 \pm 0.77$ & 1 & $4.6 \pm 0.54$ & 2 & .87 \\
Evidence-based practice & $4.2 \pm 0.98$ & 4 & $4.06 \pm 0.99$ & 6 & $4.75 \pm 0.5$ & 1 & .34 \\
Role of clinical professional & $4.27 \pm 0.93$ & 2 & $3.98 \pm 1.15$ & 8 & $4.75 \pm 0.5$ & 1 & .11 \\
Role of non-clinical Professional & $3.56 \pm 1.05^{*}$ & 10 & $4.13 \pm 0.85^{*}$ & 5 & $4.0 \pm 0.8$ & 7 & $.04^{*}$ \\
Information systems & $4.11 \pm 0.95$ & 7 & $4.26 \pm 0.9$ & 2 & $4.0 \pm 1.4$ & 8 & .59 \\
Referral systems & $4.23 \pm 0.84$ & 3 & $3.98 \pm 1.13$ & 7 & $4.0 \pm 0.7$ & 6 & .23 \\
Conflict issues in healthcare workforce & $3.58 \pm 1.15$ & 9 & $3.49 \pm 1.2$ & 10 & $4.25 \pm 0.9$ & 4 & .45 \\
New technology & $3.92 \pm 1.02$ & 8 & $3.91 \pm 0.92$ & 9 & $4.75 \pm 0.5$ & 1 & .25 \\
Infection control practices & $4.18 \pm 1.05$ & 5 & $4.17 \pm 1.05$ & 3 & $4.2 \pm 0.83$ & 5 \\
\hline Note. Test statistics- Anova and post-hoc test; ${ }^{*} p<.05$ & & & & &
\end{tabular}

The most important competencies in the communication and relationship domain is shown in Table 2. There was a statistically significant difference in the rating for business communication between operational and strategic managers $(p=.04)$.

The professionalism domain showed that operational, middle and strategic managers rated ethical principles most important with mean scores of $4.31 \pm 0.93,4.51 \pm 0.74$ and 5 (see Table 3).
In the leadership domain, decision making was considered most important by both operational and middle managers with mean scores of $4.28 \pm 0.86$ and $4.45 \pm 0.7$ respectively. Four items were rated at the same level of importance by the strategic managers. There were leadership theories, styles and situational application; decision making, support innovation/creativity (motivational) and mentoring/coaching principles with mean scores of $4.8 \pm 0.44$ each (see Table 4 ). 
Table 2. Importance rating of competency statements on communication/relationship management

\begin{tabular}{|c|c|c|c|c|c|c|c|}
\hline Knowledge item & $\begin{array}{l}\text { Operational } \\
\text { manager }\end{array}$ & Rating & $\begin{array}{c}\text { Middle } \\
\text { manager }\end{array}$ & Rating & $\begin{array}{l}\text { Strategic } \\
\text { manager }\end{array}$ & Rating & $p$-value \\
\hline $\begin{array}{l}\text { Communicate hospital's mission, vision } \\
\& \text { objectives }\end{array}$ & $4.26 \pm 0.85$ & 3 & $4.36 \pm 0.78$ & 2 & $4.4 \pm 0.89$ & 4 & .71 \\
\hline Team building techniques & $4.35 \pm 0.77$ & 1 & $4.34 \pm 0.73$ & 3 & $4.6 \pm 0.54$ & 2 & .76 \\
\hline $\begin{array}{l}\text { Provide and receive constructive } \\
\text { feedback }\end{array}$ & $4.14 \pm 0.92$ & 5 & $4.1 \pm 0.71$ & 10 & $4.25 \pm 0.95$ & 5 & .92 \\
\hline Constructive performance evaluation & $4.1 \pm 0.88$ & 8 & $4.16 \pm 0.73$ & 8 & $4.4 \pm 0.89$ & 4 & .68 \\
\hline Effective counseling strategies & $4.26 \pm 0.75$ & 2 & $4.2 \pm 0.88$ & 7 & $4.4 \pm 0.89$ & 4 & .81 \\
\hline Effective disciplinary strategies & $4.11 \pm 0.87$ & 7 & $4.28 \pm 0.88$ & 5 & $4.4 \pm 89$ & 4 & .4 \\
\hline $\begin{array}{l}\text { Delivery of credible reports using modern } \\
\text { communication gadgets e.g. power point }\end{array}$ & $4.12 \pm 0.96$ & 6 & $4.12 \pm 1.07$ & 9 & $4.6 \pm 0.54$ & 2 & .55 \\
\hline Preparation of business communication & $3.95 \pm 0.99^{*}$ & 10 & $4.32 \pm 0.83$ & 4 & $5^{*}$ & 1 & $.04^{*}$ \\
\hline $\begin{array}{l}\text { Mediation, conflict \& dispute resolution } \\
\text { techniques }\end{array}$ & $3.97 \pm 0.97$ & 9 & $4.25 \pm 0.88$ & 6 & $4.6 \pm 0.54$ & 2 & .08 \\
\hline Patients' rights and responsibilities & $4.22 \pm 0.07$ & 4 & $4.4 \pm 0.9$ & 1 & $4.6 \pm 0.89$ & 3 & .36 \\
\hline
\end{tabular}

Table 3. Importance rating of competency statements on professionalism

\begin{tabular}{lccccccc}
\hline Knowledge item & $\begin{array}{c}\text { Operational } \\
\text { manager }\end{array}$ & Rating & $\begin{array}{c}\text { Middle } \\
\text { manager }\end{array}$ & Rating & $\begin{array}{c}\text { Strategic } \\
\text { manager }\end{array}$ & Rating & $\boldsymbol{p}$-value \\
\hline Ethical principles & $4.31 \pm 0.93$ & 1 & $4.51 \pm 0.74$ & 1 & 5 & 1 & .13 \\
Strategic planning & $4.21 \pm 0.85$ & 4 & $4.35 \pm 0.75$ & 3 & $4.25 \pm 0.5$ & 7 & .6 \\
$\begin{array}{l}\text { Policy formulation \& analysis } \\
\text { Systems theories \& thinking }\end{array}$ & $3.96 \pm 1.08$ & 7 & $4.23 \pm 0.83$ & 5 & $4.4 \pm 0.5$ & 5 & .2 \\
$\begin{array}{l}\text { Healthcare management } \\
\text { theories }\end{array}$ & $3.77 \pm 1.02$ & 9 & $3.87 \pm 0.95$ & 9 & $4.4 \pm 0.89$ & 6 & .35 \\
$\begin{array}{l}\text { Professional standards \& } \\
\text { codes of conduct }\end{array}$ & $4.3 \pm 0.87$ & 2 & $4.29 \pm 0.94$ & 4 & $4.5 \pm 0.57$ & 4 & .9 \\
$\begin{array}{l}\text { Continuing education \& } \\
\text { career development }\end{array}$ & $4.26 \pm 0.95$ & 3 & $4.48 \pm 0.77$ & 2 & $4.6 \pm 0.54$ & 3 & .24 \\
$\begin{array}{l}\text { Membership of professional } \\
\text { organizations }\end{array}$ & $4.17 \pm 1.03$ & 5 & $4.23 \pm 0.95$ & 6 & $4.4 \pm 0.89$ & 6 & .84 \\
Quality/process improvement & $4.07 \pm 0.92$ & 6 & $4.17 \pm 0.88$ & 7 & $4.8 \pm 0.44$ & 2 & .18 \\
\hline
\end{tabular}

Note. Test statistics- Anova and post-hoc test

The business/financial management domain showed that operational managers considered operational and capital budget fore-casting most important with a mean score of $3.98 \pm 1.74$. Middle managers rated audit of operations and systems most important with a mean score of $4.13 \pm 0.84$. Strategic managers rated cost benefit and cost effectiveness analysis as most important with mean scores of $4.8 \pm 0.44$ (see Table $5)$.

The frequency of 5 rated (essential) competencies for each competency domain by the different categories of managers showed that for operational managers, professional skills had the highest frequency of 5 rating $(59.3 \%)$ and change process/management had the lowest frequency of 5 rating (19.2\%). For middle managers, ethical principles and continuing education/career development had the highest frequency of 5 rating $(58.5 \%)$ respectively and change process and conflict issue in healthcare workforce had the lowest frequency of 5 rating $(20.7 \%)$. For strategic managers, business communication had the highest frequency of 5 rating (100\%) while role of non-clinical professionals, referral systems and strategic planning had the lowest frequency of 5 rating $(20 \%)$. 
Table 4. Importance rating of competency statements on leadership domain

\begin{tabular}{lccccccc}
\hline Knowledge item & $\begin{array}{c}\text { Operational } \\
\text { manager }\end{array}$ & Rating & $\begin{array}{c}\text { Middle } \\
\text { manager }\end{array}$ & Rating & $\begin{array}{c}\text { Strategic } \\
\text { manager }\end{array}$ & $\begin{array}{c}\text { Rating } \\
\boldsymbol{p} \text {-value }\end{array}$ \\
\hline $\begin{array}{l}\text { Leadership theories styles \& } \\
\text { situational application }\end{array}$ & $4.09 \pm 0.85$ & 3 & $4.15 \pm 0.82$ & 6 & $4.8 \pm 0.44$ & 1 & .17 \\
$\begin{array}{l}\text { Decision making } \\
\text { Staff retention strategies }\end{array}$ & $4.28 \pm 0.86$ & 1 & $4.45 \pm 0.71$ & 1 & $4.8 \pm 0.44$ & 1 & .18 \\
$\begin{array}{l}\text { Change process \& management } \\
\text { Stress management }\end{array}$ & $3.84 \pm 1.02$ & 7 & $4.13 \pm 0.73$ & 7 & $4.2 \pm 1.09$ & 4 & .14 \\
$\begin{array}{l}\text { Interdisciplinary work } \\
\text { coordination }\end{array}$ & $4.04 \pm 1.03$ & 6 & $4.22 \pm 0.96$ & 5 & $4.6 \pm 0.54$ & 2 & .28 \\
$\begin{array}{l}\text { Support innovation \& } \\
\text { creativity (motivational) }\end{array}$ & $4.04 \pm 1.01$ & 5 & $4.25 \pm 0.78$ & 4 & $4.6 \pm 0.54$ & 2 & .21 \\
$\begin{array}{l}\text { Mentoring/coaching principles } \\
\text { Note. Test statistics- Anova and post-hoc test }\end{array}$ & $4.2 \pm 0.93$ & 2 & $4.28 \pm 0.82$ & 3 & $4.8 \pm 0.44$ & 1 \\
\hline
\end{tabular}

Table 5. Importance rating of competency statements on leadership domain

\begin{tabular}{|c|c|c|c|c|c|c|c|}
\hline Knowledge item & $\begin{array}{l}\text { Operational } \\
\text { manager }\end{array}$ & Rating & $\begin{array}{c}\text { Middle } \\
\text { manager }\end{array}$ & Rating & $\begin{array}{l}\text { Strategic } \\
\text { manager }\end{array}$ & Rating & $p$-value \\
\hline Cost-benefit analysis & $3.9 \pm 1.06$ & 5 & $4.1 \pm 0.88$ & 2 & $4.8 \pm 0.44$ & 1 & .08 \\
\hline Cost-effectiveness analysis & $3.91 \pm 1.05$ & 4 & $4.04 \pm 0.84$ & 6 & $4.8 \pm 0.44$ & 1 & .11 \\
\hline $\begin{array}{l}\text { Performance of audits of } \\
\text { operations \& systems }\end{array}$ & $3.76 \pm 1.11$ & 8 & $4.13 \pm 0.84$ & 1 & $4.6 \pm 0.89$ & 3 & .13 \\
\hline Inventory control systems & $3.93 \pm 1.01$ & 3 & $4.06 \pm 0.81$ & 3 & $4.6 \pm 0.89$ & 3 & .24 \\
\hline Productivity measurements & $3.96 \pm 1.04$ & 2 & $3.94 \pm 0.98$ & 8 & $4.6 \pm 0.89$ & 3 & .38 \\
\hline $\begin{array}{l}\text { Operational \& capital budget } \\
\text { forecasting and generation }\end{array}$ & $3.98 \pm 1.74$ & 1 & $4.06 \pm 1.06$ & 5 & $4.6 \pm 0.89$ & 3 & .67 \\
\hline $\begin{array}{l}\text { Prepare and analyze financial } \\
\text { statements }\end{array}$ & $3.88 \pm 1.16$ & 6 & $4.02 \pm 1.02$ & 7 & $4.4 \pm 0.89$ & 4 & .45 \\
\hline Risk management strategies & $3.79 \pm 1.13$ & 7 & $4.06 \pm 1.01$ & 4 & $4.6 \pm 0.54$ & 2 & .1 \\
\hline $\begin{array}{l}\text { Principles of public-private } \\
\text { partnership }\end{array}$ & $3.65 \pm 1.19$ & 9 & $3.68 \pm 1.13$ & 9 & $4.4 \pm 0.89$ & 4 & .57 \\
\hline
\end{tabular}

\section{RESULT OF QUALITATIVE DATA ANALYSIS}

\subsection{Health care environment domain}

Of the ten questions in this domain, most of the managers considered clinical/technical skills related to their profession and research and evidenced based practices as very important followed by regulatory agency standards and role of clinical professionals. These competencies are essential to the delivery of high quality of healthcare services. "My expertise in clinical/technical skills related to my profession enables me to do my work properly and with confidence" - Operational manager. I can train and supervise the junior staff effectively-Operational manager.

New technology and conflict issues in the healthcare workforce were considered least important by more than $50 \%$ of the managers. New technology in terms of equipments is not readily available and even the ones that are available are not fully utilized and get easily damaged due to incessant power outage.

"Once I was required to present a paper on new technology in my workplace abroad, the only thing I could classify as new technology was pulse oximeter which we use one per ward of 10-25 patients" - Operational Manager.

The managers concurred that conflict occurs because of poor knowledge of role of clinical and non-clinical professionals in the healthcare environment and in-fighting between professional groups.

"Clinical professionals do not adequately appreciate the 
role of non-clinical professionals. There is also tussle for supremacy amongst clinical professionals" - Middle manager.

\subsection{Communication domain}

Most of the managers rated team building techniques and communication of hospital's mission, vision and objectives as very important. This was followed by provision and reception of constructive feedback and constructive performance evaluation. The managers agreed that every hospital should have a mission statement which drives processes in the organization and helps it to channel resources towards achievement of its set goals and objectives. However, most of the middle and operational managers are not aware of the hospital's mission statement. Thus, they are unable to communicate such to the staff in their department and teams.

"I have not seen this hospital's mission statement. I went to the hospital's website, it was not there. Neither was it at the hospital's reception" - Operational manager.

"I stumbled across it in the hospital's magazine while I was preparing for my promotion interview. It has never been formally communicated to me since I became a manager" Operational manager.

Team building techniques was also considered very important because strong team makes for efficient healthcare delivery systems. In building strong teams, every member should be made to feel important and their contribution appreciated. Feedback was considered very important by more than half of the team members. Feedback should be bi-directional; from clients and from superiors. Some managers had concerns about receiving feedback from subordinates as this may be misleading.

"Feedback from junior colleagues tends to be positive with the intention to massage the ego" - Strategic manager.

Some managers reported that patients' rarely are provided with the opportunity to give feedback. Although the hospital has put in place structures such as SERVICOM to facilitate provision/reception of feedback from patients, these organs do not function effectively.

"Feedback is key to the operational manager if he/she is to improve service delivery" - Operational manager.

\subsection{Professionalism domain}

In this domain, most managers considered ethical principles as essential skill. This was followed by strategic planning, policy formulation, systems thinking and continued professional/career development. The later was seen as necessary for building strong teams and maintaining professional stan- dards and codes of conduct which in turn reduces conflict issues. Managers at the middle and operational level identified as a misnomer the process of development of a strategic plan that is top-bottom rather than bottom-up and often times do not reflect the aspirations of the various departments.

"Systems thinking is important because it enables one to visualize tertiary hospitals as a single entity with various components working together for a common goal" - Middle manager.

Membership of professional organizations was considered least important by $>50 \%$ of the managers as members have a tendency to align with the dictates of these organizations to the detriment of the common good.

"Professional bodies always canvassing for benefits only for their members breed ill feeling and aggravate conflict within the healthcare system" - Middle manager.

\subsection{Leadership domain}

Though most of the managers identified decision making as a key competency in this domain, a few cautioned that it has to be based on accurate information following extensive and inclusive consultation such that risks that may arise from the decision is anticipated and pre-empted. Leadership styles and situational application was also considered very important in the coordination of team work because teams consist of very senior and junior members with diverse professional background and experience. Most expressed views that a good manager should be able to carry each member along.

Mentoring and coaching principles was also considered very important because it was viewed as an opportunity to bequeath core values and knowledge to younger colleagues. A few however opined that mentoring is not feasible in our environment.

"People are corrupt. Sometimes mentors demand reward from mentees. People form cliques in the process of mentoring" Operational manager.

A few of the managers considered change process to be very important because the healthcare environment is dynamic and constantly undergoing changes in terms of structure, service delivery processes and expected outcomes.

"If this our profession must continue to be relevant, we must make changes every week, every month, every year" - Operational manager.

\subsection{Business/financial management domain}

In this domain, more than half of the managers identified principles of public private partnership as the most important competency. They were of the view that public-private part- 
nership is a viable option for the development and provision of standard healthcare practices to forestall medical tourism in the face of dwindling Federal Government allocation to the health sector. Audit of operation and systems was considered the second most important followed by cost-effectiveness analysis and productivity measurements. The view of one manager who considered preparation and analysis of financial statements as very important is noteworthy.

"Analysis of financial statement, in conjunction with productivity measurements, guides budgeting and decision making in terms of prioritization of scarce resources. However, in our environment where essential resources for work such as water, electricity, oxygen etc are not in constant supply, it may be difficult to measure staff productivity" - middle manager.

\section{Discussion}

This study showed that managers in a typical healthcare institution in Nigeria still consider clinical and technical skill related to one's profession to be very important in their managerial role. This is in contrast to findings by Chilanga et al. ${ }^{[15]}$ They reported that managers in their study considered skills related to human relationship as more important than technical skills; Although managers considered team building as essential which was similar to what was reported in a study on nurse manager competences, ${ }^{[16]}$ conflict issues, constructive feedback which are the bane of building strong teams were not considered as important. This finding underscores the fact that managers do not appreciate the basic requirement for team building and multi-disciplinary work coordination which is lacking in most Nigerian tertiary hospitals. ${ }^{[7]}$ The role of the non-clinical professional was also not considered significantly important across the three managerial levels. This is in contrast to other studies where non-clinical professionals are managers of the healthcare institution. ${ }^{[17]}$

Decision making was considered essential at all levels of management but information systems which is the mainstay of good decision making was not considered as important. This highlights a major problem in the process of decision making that is not based on adequate and accurate information. Strategic planning, policy formulation and systems thinking were not considered as essential even by strategic managers. This finding reiterates the need for managers of tertiary hospitals especially at the strategic level to acquire new skill sets especially those related to strategic planning, organization and systems thinking. ${ }^{[18,19]}$

All items in the business domain had mean scores of $<4$ and were not considered to contribute significantly to the role of operational mangers. This finding is similar to what was documented amongst middle healthcare managers in Nepal. ${ }^{[20]}$ Pillay ${ }^{[17]}$ had clearly demonstrated that hospitals managed by professional managers had better performance indices than those managed by clinical managers. The low rating for competencies in the business domain may underline the difference in performance between healthcare institutions in Nigeria and developed countries such as the USA and UK where most healthcare institutions are managed by professional managers or Physicians with explicit training in management. ${ }^{[3,4]}$

The results of the qualitative data did not synchronize with the quantitative data to some extent. It however provided insight on participants' responses. For instance, the opinion expressed by the middle manager on productivity measurements underlies the difficulty in ensuring staff productivity because even in situations where skilled manpower is available, basic work requirements are lacking. This situation is not peculiar to developing economies as shown in this quote extracted from a study in Zambia. ${ }^{[21]}$

"We try our best to ensure that the items that they need to conduct the services and perform better are available, these we provide whenever they need in the department........". Suggesting that sometimes materials needed for service delivery may be lacking.

The poor communication of hospital's policy, mission and vision observation in this study is at variance with report from a study on "establishing common leadership strategies and their influences on providers" by Mulenga et al. ${ }^{[21]}$ The authors noted that regular communication between managers and staff on recent policies and developments improved staff performance as shown in this quote:

"We do notify the staff of new policies or guidelines received from the Ministry, we also make sure that department are speaking to each other on the noted problem, it can be clinical, administrative or human resource issue and we take they suggestions...."

The importance of change process as a key management competency was highlighted in the qualitative study although it was not perceived to be significantly important in the quantitative data. Studies have shown that change helps to develop and evolve a hospital and for change to occur successfully there must be strategies such as training programs to fully inform all participants of the forthcoming change. Otherwise, it will be resisted. ${ }^{[22]}$ The health care industry is very dynamic with continuously emerging and re-emerging disease conditions and also continuously evolving processes and technologies in patient care. Thus, change is constant and healthcare managers have a responsibility to ensure seamless 
and timely transition of processes and technologies for optimum care delivery. This in my opinion will contribute to reducing the high rate of medical tourism in our environment.

\section{Conclusions}

The findings of this study highlights the incongrous paradigm between managerial level and perceived important management competencies and supports the belief that there is inadequate managerial capacity especially those related to financial/business management at all levels of management in a typical tertiary healthcare institution in Nigeria.

\subsection{Limitations of the study}

The study focused on strategic, middle and operational managers in a typical tertiary hospital in Nigeria and may not be representative of the opinion of such managers in other tertiary hospitals.

Secondly, since the study was based on managers' perception of predetermined competencies, responses are unlikely to reflect that of peers and subordinates.

\section{CONFLICTS OF INTEREST DisClOSURE}

The authors declare they have no conflicts of interest.

\section{REFERENCES}

[1] Baker GR. Healthcare managers in the complex world of healthcare. Frontiers of Health Service Management. 2001; 18(2): 23-32. https://doi.org/10.1097/01974520-200110000-00005

[2] Schwartz RW, Pogge C. Physician Ledership; Essential skills in a changing environment. American Journal of Surgery. 2000; 180: 187192. https://doi.org/10.1016/S0002-9610(00)00481-5

[3] Goodall AH. Physician leaders and hospital performance: Is there an association? Soc Sci Med. 2011 Aug; 73(4): 535-539.

[4] Horton R. The Darzi vision: Quality, engagement, and professionalism. The Lancet. 2008; 372: 3-4. https ://doi .org/10.1016/S0 140-6736 (08) 60963-0

[5] Gunderman R, Kanter S. Educating physicians to lead hospitals. Academic Medicine. 2009; 84: 1348-1351. PMid: 19881420. https: //doi.org/10.1097/ACM.0b013e3181b6eb42

[6] Adebimpe OW, Owolade OA, Adebimpe MA. Health workers' perception of the use of strikes as a tool for dispute resolution in Lagos state, Nigeria. Journal of Social Sciences and Public Policy. 2010; 2: 19-23.

[7] Aina O. Health care in Nigeria can't improve beyond health workers capacity to manage well. Nigerian Health Journal. 2011. Available from: www.nigeriahealthjournal.com

[8] Oladejo EI, Umeh OL, Egolum CC. The challenge of healthcare facilities maintenance in tertiary hospitals in south-east Nigeria. International Journal of Civil Engineering Construction and Estate Management. 2015; 3(2): 1-6.

[9] Chouhan VS, Srivastava S. Understanding competencies and competency modeling-A literature survey. IOSR Journal of Business and Management (IOSR-JBM). 2014; 14-22. https://doi.org/10.9 $790 / 487 X-16111422$

[10] Sanchez R. Success factors, competitive advantage and competence development. Journal of Business Research. 2004; 57(5): 518-532. https://doi .org/10.1016/S0148-2963(02) 00318-1

[11] Braithwaite J. An empirically based model for clinician-managers' behavioral routines. Journal of Health Organization and Management. 2004; 18(4): 240-261. PMid: 15536754. https://doi.org/10.1 $108 / 14777260410554269$

[12] Boyatzis R. Competencies in the 21st century. Journal of Management Development. 2007; 27(1): 5-12. https://doi .org/10.110 $8 / 02621710810840730$
[13] Stelf E. Common competencies for All healthcare Managers: The Healthcare Leadership Alliance Model. Journal of Healthcare Management. 2008; 53(6): 360-375. https ://doi .org/10.1097/00 115514-200811000-00004

[14] Charan J, Biswas T. How to calculate sample size for different study designs in medical research. Indian Journal of Psychological Medicine. 2013; 35(2): 121-126. PMid: 24049221. https: //doi.org/10.4103/0253-7176.116232

[15] Chilanga CC, Mwanza C, Karodia AM. An evaluation of middle management skills in private healthcare service in the Western Cape Province, South Africa. Arabian. Journal of Business and Management Review. 2014; 4(1). https://doi .org/10.12816/0016573

[16] Chase LK. Nurse Manager competencies. Journal of Nursing Administration. 1994; 24(4): 56-64. PMid: 8151436. https://doi.org/ 10.1097/00005110-199404011-00009

[17] Pillay R. Managerial Competencies of Hospital Managers in South Africa: A survey of managers in public and private sectors. Human Resource for Health. 2008; 6: 4-9. PMid: 18257936. https: //doi.org/10.1186/1478-4491-6-4

[18] Adindu A. The need for effective management in African health systems. Journal of Health Management. 2013; 15(1): 1-13. https: //doi.org/10.1177/0972063413486053

[19] Adindu A, Asuquo A. Training human resource for 21st century Nigerian health sector. Global Journal of Human Resource Management. 2013; 1(3): 1-11.

[20] Khada DK, Gurung M, Chanlagain N. Managerial competencies - A survey of hospital managers' working in Kathmandu valley, Nepal. Journal of Hospital Administration. 2014; 3: 62-67. https: //doi.org/10.5430/jha.v3n1p62

[21] Mulenga RM, Nzala S, Mutale W. Establishing common leadership practices and their influence on providers and service deliveryin selected hospitals in Lusaka province, Zambia. Journal of Public Health in Africa. 2018. PMid: 30854175. https://doi.org/10.4081/ jphia. 2018.823

[22] Belias D, Velissariou S, Papailias S, et al. Change managementobstacles and perspectives for integration of changes in Greek public hospitals. Advances in Management and Applied economics. 2019; 9(2): 37-50. 